\title{
Exploring Students' Problem-solving Ability and Response towards Metacognitive Strategy in Mathematics Learning
}

\author{
Masduki*, Muhammad Noor Kholid, Rita Pramujiyanti Khotimah \\ Faculty of Education and Teacher Training, Universitas Muhammadiyah Surakarta (UMS), Surakarta, Indonesia
}

Received January 6, 2020; Revised May 28, 2020; Accepted July 16, 2020

Copyright ( 02020 by authors, all rights reserved. Authors agree that this article remains permanently open access under the terms of the Creative Commons Attribution License 4.0 International License

\begin{abstract}
Purpose: This study aims to investigate students' problem-solving abilities and responses during involving metacognitive strategy in learning. Methodology: This study used one group pre-test post-test design. The participants of this study were thirty-one first semester students of the Department of Mathematics Education, Universitas Muhammadiyah Surakarta. All participants have been enrolled in elementary mathematics courses. The data were collected by using tests and questionnaires. Before the first lesson has begun, students were given a pre-test to solve three contextual problems. Furthermore, the learning is carried out by integrating the metacognitive strategy for one and a half months. At the end of the lesson, the students were provided a post-test that consists of two contextual problems. Results:The result of the t-test showed that t-value $=-7.937<\mathrm{t}$-table $=-2.0423$. It can be concluded that there were significant differences between pre-test and post-test. Performance of the student's problem-solving abilities has increased after involving metacognitive strategy in learning with an average score of 73.5, compared to the pre-test with an average score of 47.9. Besides, students provide a positive response while engaging a metacognitive strategy in learning. Applications/Originality/Value: Involving metacognitive strategy in learning can enhance student's problem-solving abilities effectively.
\end{abstract}

Keywords Problem Solving Ability, Metacognitive, Contextual Problem

\section{Introduction}

The essence of learning Mathematics can use the knowledge possessed to solve mathematical problems
(NCTM, 2000). Problem solving is a complex problem, non-routine, open, challenging, and there are no routine methods or ways that can be used to solve problems (Blum \& Niss, 1991; Schoenfeld, 1992; NCTM, 2000). Meanwhile, Gravemeijer \& Doorman (1999) defines the problem solving as a problem describing the real-world situation according to the students' experience. The World Economic Forum (2016) formulated problem solving as one of the skills needed in the future of jobs in the 21st century. Problem solving, according to the World Economic Forum, is the ability to solve problems that are ill-defined and related to the real-world.

Real-world problems or contextual problems are the essences of mathematical Learning (MAA, 1998; NCTM, 2000). Students are required to use the mathematical concepts and/or procedures that have been studied to solve the problem. In solving the problem, students should be able to interpret problems, symbolize, manipulate, and resolve them by applying mathematical procedures or operations (Seifi, et al, 2012). The problem-solving is the cognitive process of using knowledge owned (OECD, 2004; Capraro, Capraro, \& Rupley, 2012; Hickendorf, 2013). Polya (1976) systematically formulates four cognitive processes in solving problems; understand problems, develop planning, implement planning, and evaluate solutions.

However, some studies have shown the difficulties of students in solving problems related to real situations. Wijaya et al. (2014) in his research investigates the mistakes that Indonesian students do in resolving the contextual problems that arise in the PISA test. The results of his research showed that in the process of problem solving, the mistake is to understand the meaning of the context of the problem (38\%) and transforms context into mathematical problems (42\%). In the process of reproduction (implementing procedures, techniques, standard algorithms), the mistakes that students do is to 
understand the problem (37\%) and transforms context into mathematical problems (34\%). Further, on the connection process, the error of understanding amounted to $41 \%$ and the transformation error of $43 \%$. In the process of reflection, understanding reaches $66 \%$. The research of Wijaya et al. (2014) shows that most of the mistakes that students do are in understanding the problems (context of problems) as well as transforming the context into mathematical problems. In line with the research of Wijaya et al. (2014), Bayazit (2013) in his research concluded that students cannot utilize the concepts that have to solve real problems. Students only use procedures, concepts, factual knowledge that is held routinely without criticism. Students struggle to use appropriate problem-solving strategies and are incapable of using alternative strategies.

The success of solving mathematical problems requires the ability to understand problems, control and monitor cognitive processes, or in other words metacognitive abilities (Karakelle 2012; Erbas and Okur, 2012; Siegel, 2012; Özsoy \& Ataman, 2017). Özsoy and Ataman divide the students into two groups where one group is given metacognitive training while the other group is not. The results showed that the group with Metacognitive training experienced a significant increase in problem solving capabilities compared to the group without treatment.

The ability of metacognitive is also a contributing element that is crucial in solving problems to assist individuals in identifying and structuring frameworks or strategies (Davidson \& Sternberg, 1998). The ability to develop problem solving strategies is one of the important factors in problem solving (Erbas and Okur, 2012). Failure to develop the right strategy will cause failure to solve the problem.

Flavell (1979) defines metacognitive as the ability to understand and monitor self-thought activities and assumptions as well as the implications of one's activities. This means that each person's processes will differ according to their ability. Meanwhile, Brown (1987) defines metacognitive as an awareness of self-cognitive activity, a method used to regulate self-cognitive processes and a mastery of how to direct, plan, and monitor cognitive activity. Besides, Schoenfeld (1987) stated that metacognitively is "thinking about our thinking" i.e. thinking how we think. There are three aspects according to Schoenfeld (1987) which are very important in the activities of metacognitively; knowledge about the process of thinking, control, and self-regulation, and beliefs and intuition. Schoenfeld (1987) stated that in the process of solving the problem, a student must monitor and keep the appropriate path during the troubleshooting process. When the strategy used does not work properly, it should try other alternative strategies.

Flavell (1979) suggests that metacognitive is made up of knowledge of metacognition, and the experience or arrangement of metacognitive. On the other hand, Brown (1987) also divides metacognitive into the knowledge of cognitive and cognitive settings. Metacognitive knowledge is described as knowledge or conviction of factors, variables affecting individual cognitive processes (Flavell, 1979). Brown (1987) distinguishes the three types of metacognitive knowledge i.e. declarative, procedural, and conditional knowledge. Furthermore, the metacognitive or well-known arrangement with metacognitive skills is defined as an awareness of self-cognitive activities, methods for regulating cognitive processes, as well as orders to organize, plan, and Regulating cognitive activity. Jacobs and Paris (1987) presents three essential components in the setting of metacognitively, which is planning, monitoring, and evaluating. While Lucangeli and Cornoldi (1997) stated four components of metacognitive skills namely prediction, planning, monitoring, and evaluation.

A metacognitive engagement in learning has been the concern of researchers to improve student problem-solving skills. Özso and Ataman (2017) demonstrated an increase in problem-solving skills of students in the class given metacognitive training. Vula, et. al (2017) shows the impact of the use of metacognitive strategies and self-arrangement in solving problems about math stories. Research that has been conducted focuses on the investigation of problem-solving skills in high school students, not many research problems solving skills in college students. For that, the study aims to explore student problem solving skills and student attitudes towards learning involving metacognitive strategies. In this study, students' ability to solve problems is seen from the ability to solve contextual questions on basic mathematics courses. Besides, students' attitudes towards learning strategies integrating metacognitive are also investigated.

\section{Research Methods}

The research uses a one-group design pre-Test post-Test because only one class is involved in research activities. A total of 31 students participated in this research activity. The metacognitive strategy in learning is implemented by integrating three metacognitive components according to Jacobs and Paris (1987) i.e. planning, monitoring, and evaluating in the learning activities. The syntax of the metacognitive strategy in learning is presented in Table 1. 
Table 1. Syntax of Metacognition and Learning Strategy

\begin{tabular}{|c|c|c|c|}
\hline & Phase & Students Activity & Lecturer Activity \\
\hline 1. & Problem Oriented & $\begin{array}{l}\text { Students read, observe, and understand contextual, } \\
\text { non-routine, or open-ended issues concerning the } \\
\text { material learned }\end{array}$ & $\begin{array}{l}\text { - Lecturers start learning by providing } \\
\text { illustrations of everyday life issues related to } \\
\text { the material to be learned } \\
\text { Lecturers provide contextual, non-routine, or } \\
\text { open-ended problems related to the materials } \\
\text { learned. } \\
\text { Lecturers guide students to observe and } \\
\text { understand the problem by asking students } \\
\text { questions like "Do you understand the intent } \\
\text { of the issue?" }\end{array}$ \\
\hline 2. & Planning & $\begin{array}{l}\text { Students identify information that is known and } \\
\text { asked in the issue and identify the information } \\
\text { necessary to resolve the issue but are not mentioned } \\
\text { in the problem } \\
\text { Students formulate or choose the right strategies to } \\
\text { solve problems based on known information } \\
\text { Students compose mathematical models to solve } \\
\text { problems }\end{array}$ & $\begin{array}{l}\text { Lecturers guide students to identify known } \\
\text { information, be asked and identify the information } \\
\text { necessary to resolve the issue by asking questions } \\
\text { such as "What knowledge do you need to solve the } \\
\text { problem?", "What's the first step you need to do to } \\
\text { resolve the issue?", "What concept do you need to } \\
\text { solve the problem?", "How is the complete } \\
\text { procedure to resolve the problem This?", "It's the } \\
\text { procedure you used to solve the problem?". }\end{array}$ \\
\hline 3. & Monitoring & $\begin{array}{l}\text { Students implement problem-solving strategies } \\
\text { Students monitor each step of completion by giving } \\
\text { arguments to each completion step written }\end{array}$ & $\begin{array}{l}\text { Lecturers guide students to monitor any completion } \\
\text { procedures done by asking questions such as, "is } \\
\text { there any calculation you do?", "Why do you do a } \\
\text { workaround like this? Give the reason ". }\end{array}$ \\
\hline 4. & Evaluation & $\begin{array}{l}\text { Students evaluate the conformity of results } \\
\text { obtained with the problems asked by checking the } \\
\text { accuracy of planning and implementation of } \\
\text { problem solving }\end{array}$ & $\begin{array}{l}\text { Lecturers guide students to re-evaluate the } \\
\text { processes and results that have been obtained by } \\
\text { asking questions such as, "is the result you have } \\
\text { gained right?", "is the procedure you use already } \\
\text { following the strategy you are planning?", "Is there } \\
\text { another more effective way to solve the question?" }\end{array}$ \\
\hline 5. & Verification & $\begin{array}{l}\text { Students present and discuss the outcome of the } \\
\text { problem-solving process with other students and } \\
\text { lecturers } \\
\text { Students formulate conclusions from problem } \\
\text { solving based on discussion results }\end{array}$ & $\begin{array}{l}\text { - Lecturers guide students in discussing the } \\
\text { completion strategy and results obtained by } \\
\text { asking several students to present their work. } \\
\text { Lecturers guide students to formulate } \\
\text { conclusions from problem solving }\end{array}$ \\
\hline 6. & Generalization & $\begin{array}{l}\text { Students develop an understanding of the concepts } \\
\text { of the material learned based on the problems that } \\
\text { have been resolved } \\
\text { Students apply concepts gained on different issues }\end{array}$ & $\begin{array}{l}\text { - Lecturers guide students to develop concepts } \\
\text { of definition, character, or completion } \\
\text { algorithm of the material learned } \\
\text { - Lecturers guide students to apply the concept } \\
\text { to different problems }\end{array}$ \\
\hline
\end{tabular}

Before the application of the metacognitive strategy in learning, researchers provided the pre-tested that consists of three contextual algebraic problems. Implementation of metacognitive strategy in learning is conducted for six weeks in the first semester of students from the Mathematics Education Department of Universitas Muhammadiyah Surakarta which enrolls the basic mathematical courses. After that, the post-test was provided using two contextual problems. Validate pre-Test and post-test problems using content validation and experts. Content validation is used to ensure compliance with the learning objectives. While the validation of experts used to ensure the accuracy of the test based on the opinion of the expert of mathematics education.

Furthermore, pre-test and post-test results were analyzed using assessments that took into account four aspects of troubleshooting according to Polya (1979). In this study the aspect of understanding the problem is broken down into two components; understanding of known information and understanding of the information asked. Similarly, the planning aspects are divided into two components; the accuracy of the problem-solving strategy and the accuracy of the selection of mathematical models used. Thus, the study used six components to measure students' problem-solving skills. Each component is given scoring by using the following criteria.

Table 2. Scoring Criteria in Problem Solving Ability

\begin{tabular}{cc}
\hline Score & Criteria \\
\hline 1 & If not showing the ability at all \\
2 & If it shows a small \\
3 & If it shows most capabilities \\
4 & If showing all the capabilities \\
\hline
\end{tabular}

Furthermore, differences in problem solving capabilities 
of pre-test results and post-test results are analyzed using the T-test. Besides, the collection of data on students' attitudes during the learning study used a questionnaire containing 10 item statements. Each item is given a scoring with the following criteria: 1 (disagree), 2 (not agree), 3 (Agree), and 4 (strongly agree). Then, the data of the questionnaire is analyzed based on percentage results on each item.

\section{Research Result and Discussion}

The averages problem-solving ability of 31 students who follow the learning activities using the metacognitive strategy on pre-Test and post-test are presented in Table 3 below.

Table 3.The average score for each indicator of students' problem-solving ability

\begin{tabular}{llcc}
\hline & \multicolumn{1}{c}{ Indicators } & Pre-test & Post-test \\
\hline 1. & Understanding of known information & 2.35 & 3.87 \\
2. $\quad \begin{array}{l}\text { Understanding of the information } \\
\text { asked }\end{array}$ & 1.6 & 3.83 \\
3. $\quad \begin{array}{l}\text { Accuracy of the problem-solving } \\
\text { strategy }\end{array}$ & 2.1 & 3.21 \\
4. Accuracy of the model used & 2 & 2.73 \\
5. $\quad$ The truth in performing a calculating & 1.8 & 2.58 \\
& $\quad$ operation & 1.5 & 1.95 \\
6. Truth Answers & $\mathbf{5 9 . 7 2}$ & $\mathbf{7 2 . 3 6}$ \\
The final average score & & \\
\hline
\end{tabular}

Table 3 shows that after students have participated in learning involving a metacognitive strategy, all indicators of problem-solving capabilities have increased based on pre-test and post-test results. In the indicator understand the known information and asked to occur a significant increase compared to other indicators. The metacognitive strategy used in learning can encourage students to have the ability to understand problems. However, on the indicators of examining the truth of the answer, the average post-test score, compared with the pre-test, only increased not more than 0.5 points. Thus there are still many students who have not done the truth check answers.

Furthermore, the T-test is carried out against the pre-test results and the post-test of all participants to test whether there are significant differences in the results of these tests. Before the T-test, pre-test and post-test data were tested for normality by using SPSS. The normality and T-test results are presented in tables 4 and 5 below.

Table 4. Result of normality test of pre-test and post-test

\begin{tabular}{|c|c|c|c|c|c|c|}
\hline \multirow{2}{*}{} & \multicolumn{3}{|c|}{ Kolmogorov-Smirnov $^{\mathrm{a}}$} & \multicolumn{3}{c|}{ Shapiro-Wilk } \\
\cline { 2 - 7 } & Statistic & $\mathrm{df}$ & Sig. & Statistic & $\mathrm{df}$ & Sig. \\
\hline Pretest & 0.148 & 31 & 0.080 & 0.945 & 31 & 0.112 \\
\hline Posttest & 0.125 & 31 & $0.200^{*}$ & 0.968 & 31 & 0.461 \\
\hline
\end{tabular}

a. Lilliefors Significance Correction

Table 4 shows that the pre-test and post-test data is a normal distribution so that the data analysis process can be quantitatively resumed. Furthermore, Table 5 indicates that the T-test score against pre-test and post-test acquired $\mathrm{t}$-value $=-7.937<\mathrm{t}$-table $=-2.0423$. This indicates that there is a significant difference between pre-test and post-test results. In other words, implementing a metacognitive strategy in learning has a significant impact on student problem-solving skills.

Table 5. Result of T-test of pre-test dan post-test

\begin{tabular}{|c|c|c|c|c|c|c|c|c|c|}
\hline & \multicolumn{5}{|c|}{ Paired Differences } & \multirow{3}{*}{$\mathrm{t}$} & \multirow{3}{*}{ df } & \multirow{3}{*}{ Sig. (2-tailed) } \\
\hline & & \multirow[t]{2}{*}{ Mean } & \multirow[t]{2}{*}{ Std. Deviation } & \multirow{2}{*}{$\begin{array}{l}\text { Std. Error } \\
\text { Mean }\end{array}$} & \multicolumn{2}{|c|}{$\begin{array}{l}\text { 95\% Confidence Interval of the } \\
\text { Difference }\end{array}$} & & & \\
\hline & & & & & Lower & Upper & & & \\
\hline Pair 1 & $\begin{array}{l}\text { Pretest - } \\
\text { Posttest }\end{array}$ & -12.64323 & 8.86962 & 1.59303 & -15.89663 & -9.38982 & -7.937 & 30 & .000 \\
\hline
\end{tabular}

Table 6. The percentage of students' response

\begin{tabular}{|c|c|c|c|c|c|}
\hline \multirow{2}{*}{$\mathrm{NO}$} & \multirow{2}{*}{ Statements } & \multicolumn{3}{|c|}{ Scoring } & \multirow[b]{2}{*}{4} \\
\hline & & 1 & 2 & 3 & \\
\hline 1 & $\begin{array}{l}\text { The learning strategy used is capable of encouraging students to apply mathematical concepts to problems } \\
\text { beyond mathematics or issues of everyday life }\end{array}$ & 3.3 & 16.4 & 70.5 & 9.8 \\
\hline 2 & $\begin{array}{c}\text { The learning strategy used is capable of encouraging students to make mature planning before solving } \\
\text { problems }\end{array}$ & 0.0 & 3.3 & 75.0 & 21.7 \\
\hline 3 & $\begin{array}{c}\text { The learning strategy used is capable of encouraging students to develop a systematic completion strategy to } \\
\text { solve problems }\end{array}$ & 0.0 & 6.6 & 67.2 & 26.2 \\
\hline 5 & $\begin{array}{c}\text { The learning strategy used can encourage students to always evaluate the implementation of the problem } \\
\text { solving }\end{array}$ & 0.0 & 8.2 & 67.2 & 24.6 \\
\hline 6 & $\begin{array}{l}\text { The learning strategy encourages students to be able to create relationships between the variables in the } \\
\text { given problem }\end{array}$ & 0.0 & 16.4 & 68.9 & 14.8 \\
\hline 7 & Learning strategy encourages students to skillfully manipulate mathematical calculations & 0.0 & 14.8 & 75.4 & 9.8 \\
\hline 8 & Learning strategy encourages students to be able to make generalization or conclusions & 0.0 & 11.5 & 78.7 & 9.8 \\
\hline 9 & The learning strategy encourages students to understand the material concepts in basic mathematical courses & 0.0 & 14.8 & 73.8 & 11.5 \\
\hline
\end{tabular}


Students' positive response to the implementation of learning involving metacognitive is also demonstrated by the questionnaire results of all participants. The summary of the survey results is presented in Table 6 .

Table 6 shows that students provide a very positive response to the implementation of learning involving a metacognitive strategy. More than $80 \%$ of students agree with all statements in the questionnaire. In other words, students feel a positive impact on following learning involving a metacognitive strategy to improved problem-solving capabilities.

Metacognitive ability is indispensable in mathematics learning, especially in solving non-routine problems or problem-solving problems. Students who can optimize their metacognitive skills can control their positive activities in solving problems so that they will get the results as expected. Skills to control cognitive abilities include the ability to understand problems and plan problem-solving strategies, the ability to monitor problem-solving processes, as well as the ability to evaluate problem-solving outcomes that have been retrieved. If the students can optimize the three components of metacognitive skills then the student will succeed in solving the problem.

The results of this study are in line with previous research results stating that a person's ability to understand the problem, control and monitor cognitive processes, or in other words metacognitive abilities will help the success of Someone in solving the problem (Mayer, 1998; Pugalee, 2001; Desoete, Roeyers, \&Buysse, 2001; Karakelle 2012; Erbas and Okur, 2012). Besides, the metacognitive ability is also a contributing element that is crucial in solving problems to assist individuals in identifying and structuring frameworks or strategies (Davidson and Sternberg, 1998). The ability to develop problem solving strategies is one of the important factors in problem solving (Erbas and Okur, 2012). Failure to develop the right strategy will cause failure to solve the problem.

\section{Conclusions}

Problem solving is an activity involving cognitive processes. Students' ability to control cognitive processes will have an impact on student success in solving problems. The involvement of a metacognitive strategy in learning has managed to improve students' problem-solving skills. The average post-test scores of students' problem solving skills experienced a significant increase compared to pre-test scores following studies involving a metacognitive strategy. Students also provide a positive response to the implementation of a metacognitive strategy in learning. More than $80 \%$ of students agree that metacognitive strategy engagement has a positive impact on the students' ability to solve problems.

However, the success of the metacognitive strategy in this study was limited in testing using one-group pre-test and post-test design. One of the disadvantages of the design of this research is that it is unable to guarantee that the metacognitive strategy is the only factor contributing to the successful improvement of student problem solving skills. This is due to the absence of variable control in this design. Thus, further testing needs to be made to ensure that the metacognitive strategy in learning is the right strategy to improve student problem-solving skills.

\section{Acknowledgement}

Researchers thanked the Directorate of Research and Community service, Ministry of Research, Technology, and higher education who have funded this research activity in competitive grant research schemes. Researchers also thanked the Research Institute of Muhammadiyah University of Surakarta who has facilitated researchers so that this research activity can run smoothly.

\section{REFERENCES}

[1] Bayazit, Ibrahim. 2013. An Investigation of Problem Solving Approaches, Strategies, and Models Used by the 7th and 8th Grade Students when Solving Real-World Problems. Educational Sciences: Theory \& Practice, 13 (3), 1920 1927.

[2] Blum, W., \& Niss, M. (1991). Applied mathematical problem solving, modelling, applications, and links to other subjects-State, trends and issues in mathematics instruction. Educational studies in mathematics, 22(1), 37-68.

[3] Brown, A. (1987). Metacognition, executive control, self-regulation, and other more mysterious mechanisms. In Weinert, F., and Kluwe, R. (eds.),Metacognition, Motivation, and Understanding, Erlbaum, Hillsdale, NJ, pp. 65-116.

[4] Capraro, R. M., Capraro, M. M., \& Rupley, W. H. (2012). Reading-enhanced word problem solving: A theoretical model. European journal of psychology of education, 27(1), 91-114.

[5] Davidson, J. E., \& Sternberg, R. J. (1998). Smart problem solving: How metacognition helps. In D. J. Hacker, J. Dunlosky, \& A. C. Graesser (Eds.), Metacognition in educational theory and practice (pp. 47-68). Mahweh, NJ: Lawrence Erlbaum Associates.

[6] Desoete, A., Roeyers, Herbert., Buysse, Ann. 2001. Metacognition and Mathematical Problem Solving in Grade 3. Journal of Learning Disabilities, 34 (5), 435 - 449.

[7] Erbas, A K., Okur, Serkan. 2012. Researching Student's Strategies, Episodes, and Metacognitions in Mathematical Problem Solving. Qual Quant, 46:89-102.

[8] Flavell, J. H., 1979, Metacognition and Cognitive Monitoring, A New Area of Cognitive - Developmental Inquiry, in Nelson, T. O. (Ed), 1992, Metacognition, Allyn and Bacon, Boston. 
[9] Hickendorff, M. (2013). The language factor in elementary mathematics assessments: Computational skills and applied problem solving in a multidimensional IRT framework. Applied Measurement in Education, 26(4), 253-278.

[10] Jacobs, J. E., \& Paris, S. G. (1987). Children's metacognition about reading: Issues in definition, measurement, and instruction. Educational psychologist, 22(3-4), 255-278.

[11] Karakelle, Sema. 2012. Interrelations Between Metacognitive Awareness, Percieved Problem Solving, Intelligence, and Need for Cognition. Education and Science, 37 (164), pp. 237-250

[12] Lester, F. K., and Kehle, P.E. (2003). From problem solving to modeling: The Evolution of thinking about reseach on complex mathematical activity. In R. A. Lesh \& H. M. Doerr (Eds.), Beyond constructivism: Models and modelling perspectives on mathematics problem solving, learning and teaching (pp. 501-517). Lawrance Erlbaum Associates Publishers.

[13] Lucangeli, D., \& Cornoldi, C. (1997). Mathematics and metacognition: What is the nature of the relationship? Mathematical Cognition, 3, 121-139.

[14] Mathematical Association of America. 1998. Quantitative literacy goals. In Quantitative reasoning for college graduates: A complement to the standards, Part II [On-line] Tersedia

di:http://www.maa.org/programs/faculty-and-departments/ curriculum-department-guidelines-recommendations/quant itative-literacy/quantitative-reasoning-college-graduates\#P reface. Diakses tanggal 4 Februari 2015.

[15] Mayer, Richard E. 1998. Cognitive, Metacognitive, and Motivational Apects of Problem Solving. Instructional Science, 26: $49-63$.

[16] National Council of Teachers of Mathematics (NCTM). 2000. Principles and Standards for School Mathematics. The Council, Reston, VA.
[17] Organisation for Economic Co-operation and Development (OECD). (2004). The PISA 2003 assessment framework: Mathematics, reading, science and problem solving knowledge and skills. OECD Publishing.

[18] Özsoy, G., \& Ataman, A. (2017). The effect of metacognitive strategy training on mathematical problem solving achievement. International Electronic Journal of Elementary Education, 1(2), 67-82.

[19] Panaoura, A., and Philippou, G., 2001, Young Pupils' Metacognitive Abilities in Mathematics in Relation to Working Memory and Processing Efficiency, www.ucy.ac.cy, Diakses tanggal 2 Desember 2014.

[20] Polya, G. 1973. How to Solve It: A New Aspect of Mathematics Method. Princeton Univesity Press, Princeton.

[21] Pugalee, David K. 2001. Writing, Mathematics, and Metacognition: Looking for Connections Through Students Work in Mathematical Problem Solving. School Science and Mathematics, 101 (5), pp. 236-245.

[22] Schoenfeld, A. H. (1992). Learning to think mathematically: Problem solving, metacognition, and sense making in mathematics. Handbook of research on mathematics teaching and learning, 334370.

[23] Vula, E., Avdyli, R., Berisha, V., Saqipi, B., \& Elezi, S (2017). The impact of metacognitive strategies and self-regulating processes of solving math word problems. International Electronic Journal of Elementary Education, 10(1), 49-59.

[24] Wijaya, Ariyadi., Heuvel-Panhuizen, Marja van den., Doorman, Michiel., Robitzsch, Alexander. 2014. Difficulties in Solving Context Based PISA Mathematics Tasks: An Analysis of Student's Errors. The Mathematics Enthusiast. Vol 11, No. 3, pp. 555 - 585

[25] World Economic Forum. (2016). The Future of Jobs: Employment, Skills and Workforce Strategy for the Fourth Industrial Revolution. Global Challenge Insight Report. 